\title{
Enhancing Soil Water Content for Increased Food Production in Semi-Arid Areas of Kenya Results From an On-Farm Trial in Mwala District, Kenya
}

\author{
Anne Karuma ${ }^{1}$, Peter Mtakwa ${ }^{1}$, Nyambilila Amuri ${ }^{1}$, Charles K. Gachene ${ }^{2} \&$ Patrick Gicheru $^{3}$ \\ ${ }^{1}$ Sokoine University of Agriculture, Morogoro, Tanzania \\ ${ }^{2}$ University of Nairobi, Nairobi, Kenya \\ ${ }^{3}$ National Agricultural Research Laboratories (KARI). Nairobi, Kenya \\ Correspondence: Anne Karuma, Sokoine University of Agriculture, P. O. Box 3151, Morogoro, Tanzania. Tel.: \\ 254-725-741-986. E-mail: annekaruma@gmail.com
}

Received: January 6, 2014 Accepted: February 7, 2014 Online Published: March 15, 2014

doi:10.5539/jas.v6n4p125 URL: http://dx.doi.org/10.5539/jas.v6n4p125

\begin{abstract}
Soil water conservation through tillage is one of the appropriate ways of addressing soil moisture deficit in rainfed agriculture. This study evaluated the effects of tillage practices on soil moisture conservation and crop yields in Mwala District, Eastern Kenya during the long rains (LR) and short rains (SR) of 2012/13. Six tillage systems: Disc plough (MB), Disc plough and harrowing (MBH), Ox-ploughing (OX), Subsoiling - ripping (SR), Hand hoe and Tied Ridges (HTR) and Hand hoe only (H) and, three cropping systems namely, sole maize, sole bean and maize - bean intercrop, were investigated in a split-plot design with four replicates. Data on soil water content was monitored at different weeks after planting and the crop yields at end of each growing season. A three-season average shows that soil water content and crop yields were higher in conventional tillage methods compared to the conservation tillage methods. Long term tillage experiments are thus required at different locations, under various environmental and soil conditions to validate the study findings.
\end{abstract}

Keywords: tillage systems, cropping systems, soil moisture, semi-arid areas, yields

\section{Introduction}

Semi-arid areas are characterized by temporal and spatial variability of rainfall. In Kenyan semi-arid areas, the rainfall is usually low and unreliable (Wamari et al., 2012). The timing and relative lengths of each growing period vary substantially with location (Mujdeci et al., 2010) and this leads to reductions in yields by up to $75 \%$ when they occur (Barron et al., 2003).

Deficit of soil water in these areas is also attributed to low infiltration rates (due to surface sealing and crusting and low organic matter content) and subsequent high runoff rates (Rockstrom et al., 2003). The conservation of soil water in semi-arid areas requires appropriate tillage practices that not only improve rain infiltration but also conserves adequate soil moisture for plant growth. Conservation tillage practices such as tied ridging, subsoiling and ripping have the potential of soil moisture retention and mitigation of intra-seasonal dry spells that often result in low productivity and crop failure (Manyatsi et al., 2011). According to FAO (2008), conservation tillage has positive effects on water productivity such as enhancing infiltration and soil moisture storage, improves timing of tillage operations and spatial distribution of soil moisture at field scale, which is crucial in dryland rainfed agriculture. Although conservation tillage is highly advocated, there is strong evidence that this kind of tillage may not be good with soils prone to surface crusting and sealing, a characteristic of most of the soils in the semi-arid areas of Kenya (Unger et al., 1991; Mujdeci et al., 2010). This study was conducted to quantify the comparative effectiveness of selected tillage practices in conserving soil moisture and improving crop yields in Mwala District, Eastern Kenya.

\section{Materials and Methods}

\subsection{Study Site Description}

The study was conducted in Mbiuni Location, Mwala District, Kenya $\left(1^{\circ} 15^{\prime} \mathrm{S}, 37^{\circ} 25^{\prime} \mathrm{E}\right)$. The study area is characterized by low, erratic and poorly distributed bimodal rainfall that makes crop production difficult under rain 
fed conditions. The long rains commence in mid March and end in May while short rains start in mid October and end in late November. The mean annual rainfall for Mwala District is $596 \mathrm{~mm}$ (Ngugi et al., 2011). Soil chemical properties at the site (Table 1) indicate there is need to supplement the nutrients in the study area in order to achieve reasonable crop yields through application of mineral fertilizers, animal manures and plant residues (Landon, 1991; Okalebo et al., 2002).

Table 1. Selected soil chemical and physical properties of the experimental site $(0-30 \mathrm{~cm})$

\begin{tabular}{llll}
\hline Soil property & Values & Soil property & Values \\
\hline $\mathrm{pH}\left(\mathrm{H}_{2} \mathrm{0}\right)$ & 6.50 & CEC cmol/kg & 6.70 \\
$\mathrm{pH}\left(0.01 \mathrm{M} \mathrm{Cacl}_{2}\right)$ & 5.61 & P ppm & 13.50 \\
$\% \mathrm{C}$ & 1.10 & Sand (\%) & 22.00 \\
$\% \mathrm{~N}$ & 0.09 & Silt (\%) & 39.00 \\
$\mathrm{~K} \mathrm{cmol} / \mathrm{kg}$ & 2.35 & Clay $(\%)$ & 39.00 \\
$\mathrm{Na} \mathrm{cmol} / \mathrm{kg}$ & 0.46 & Textural Class & Clay loam \\
$\mathrm{Ca} \mathrm{cmol} / \mathrm{kg}$ & 2.31 & Bulk density $\left(\mathrm{g} / \mathrm{cm}^{3}\right)$ & 1.27 \\
$\mathrm{Mg} \mathrm{cmol} / \mathrm{kg}$ & 0.39 & Saturated hydraulic conductivity $(\mathrm{Ksat})(\mathrm{cm} / \mathrm{hr})$ & 0.27 \\
\hline
\end{tabular}

\subsection{Experimental Design and Layout}

The trials were established during the long rains (LR) and short rains (SR) of 2012/13 (LR, 2012, SR 2012 and LR, 2013). Six tillage systems; Disc plough (MB), Disc plough and Harrowing (MBH), Ox-ploughing (OX), Hand hoe and Tied Ridges (HTR), Hand hoe only $(\mathrm{H})$ and subsoiling - ripping (SR), three cropping systems namely, sole maize, sole bean and maize-bean intercrop were investigated in a split-plot design with four replications. Soil moisture was monitored from crop emergence to the time of harvesting at depths of $0-20 \mathrm{~cm}$ and $20-40 \mathrm{~cm}$ using the gravimetric method (Okalebo et al., 2002).

\subsection{Crop Management}

The dryland maize variety (DH 02) and beans (rose coco - GLP 2) were used as the test crops. These crops were planted in rows in $25 \mathrm{~m}^{2}$ plots. Maize were planted at a spacing of $90 \times 30 \mathrm{~cm}$ in pure stands while in the intercropping system at $90 \times 60 \mathrm{~cm}$. Beans were planted at spacing of $45 \times 30 \mathrm{~cm}$. Maize was planted in the same row but in alternating hills at the same spacing in the tied ridging plots.

\subsection{Crop Measurements}

In order to assess crop growth, the following maize growth parameters were collected: maize plant height, cob weights, cob lengths, maize stover yield and maize grain yield. For beans, the grain and biomass yields were measured. Final crop biomass and grain yields were determined from plants harvested in a sample area of $2 \times 2$ $\mathrm{m}$ at the centre of the plot. Ten maize plants were harvested in each plot, dried and threshed by hand, adjusting the grain to $12.5 \%$ moisture. The harvest index (HI \%) of each crop was then calculated as the ratio of the grain dry weight to the above ground plant biomass yield. The soil and yield data collected were subjected to analysis of variance (ANOVA) to evaluate the treatment effects using Genstat $14^{\text {th }}$ Edition statistical software.

\section{Results and Discussion}

\subsection{Soil Water Content Trends as Affected by Tillage Practices}

Soil water content decreased over time during the growing seasons (LR, 2012, SR 2012, LR, 2013) at different weeks after planting (WAP) $(\mathrm{p}<0.001)$. In all the seasons, the soil water content was higher in the $20-40 \mathrm{~cm}$ than in the $0-20 \mathrm{~cm}$ depth and varied among the different tillage methods $(\mathrm{p}<0.001)$. The changes in profile soil water content observed could be attributed to a combination of rainfall, soil evaporation, transpiration or crop water uptake (Mujdeci et al., 2010).

In LR, 2012, there were some significant interactions between time $\times$ depth $(\mathrm{p}<0.001)$ and between time $\times$ tillage $\times$ cropping system $(\mathrm{p}=0.005)$. Soil water content trend in the $0-20 \mathrm{~cm}$ was in the order of HTR $>$ $\mathrm{MBH}>\mathrm{H}>\mathrm{OX}>\mathrm{MB}$ while in the $20-40 \mathrm{~cm}$ in the order of HTR $>\mathrm{OX}>\mathrm{MBH}>\mathrm{H}>\mathrm{MB}$. At both depths, the soil water trend was HTR $>\mathrm{MBH}>\mathrm{H}>\mathrm{OX}>\mathrm{MB}(\mathrm{p}=0.019)$. The tied ridges (HTR) had high moisture levels due to the microbasin formation allowing more storage and infiltration. According to Guzha (2004), the higher 
soil water content reported in ridges has been associated with higher roughness resulting from ridge configuration through tillage and has benefits of harvesting rainwater and increasing the time for infiltration. Similar findings have been reported by Motsi et al. (2004) in Zimbabwe where tied ridges retained soil water content significantly better than conventional tillage especially in the dry months.

In the short rains (SR, 2012), there were significant interactions between time $\times$ cropping system $(p=0.003)$ and time $\times$ depth $(p<0.001)$. There were no variations within the tillage methods $(p=0.158)$. Soil water content trend in the $0-20 \mathrm{~cm}$ was in the order of $\mathrm{OX}>\mathrm{SR}>\mathrm{MB}>\mathrm{H}>\mathrm{HTR}>\mathrm{MBH}$ while in the $20-40 \mathrm{~cm}$ was in the order of $\mathrm{OX}>\mathrm{SR}>\mathrm{HTR}>\mathrm{MB}>\mathrm{MBH}>\mathrm{H}$. At both depths, the soil water trend was at $\mathrm{OX}>\mathrm{SR}>\mathrm{MB}>$ $\mathrm{HTR}>\mathrm{H}>\mathrm{MBH}$.

In the long rains (LR, 2013), some significant interactions were noted within tillage methods $(p=0.003)$, depth $(\mathrm{p}<0.001)$, time $\times$ tillage $(\mathrm{p}<0.001)$, time $\times$ cropping system $(\mathrm{p}=0.044)$ and time $\times$ depth $(\mathrm{p}<0.001)$. Soil water content trend in the $0-20 \mathrm{~cm}$ was in the order of SR $>\mathrm{OX}>\mathrm{H}>\mathrm{MB}>\mathrm{MBH}>\mathrm{HTR}$ while in the $20-40$ $\mathrm{cm}$ was in the order of $\mathrm{OX}>\mathrm{SR}>\mathrm{H}>\mathrm{MB}>\mathrm{MBH}>\mathrm{HTR}$. At both depths, the soil water content trend was at OX $>$ SR $>$ H $>$ MB $>$ MBH $>$ HTR. Contrast to LR, 2012, HTR had the lowest soil water in the LR, 2013. Similar findings have been reported by Gicheru et al. (1998) working in the marginal areas of Laikipia district. They found that tied ridging conserved the lowest soil water amount and attributed this to high evaporation losses due to increased soil surface area.

When the amount of soil water content for each tillage method was averaged for the three seasons, a seasonal difference was found $(\mathrm{p}<0.001)$ and the trend was $\mathrm{OX}>\mathrm{H}>\mathrm{MB}>\mathrm{MBH}>\mathrm{HTR}>\mathrm{SR}$. These results show that the conventional tillage practices had the highest soil water content as compared to the conservation tillage methods. Rashidi and Keshavarzpour (2008) reported that conventional tillage increased soil water content due to the effect of the primary and secondary tillage implements used which improved porosity and water holding capacity of a clay loam soil in Iran. However, Fabrizzi et al. (2005) reported an increase of soil water storage under conservation soil tillage due to decreases of evaporation, increases of the soil infiltration, and the enhanced soil protection from rainfall impact.

\subsection{Effect of Cropping Systems on Soil Water Content Trends}

The soil water content trends connote differences in the magnitude of soil water storage within the root zone and at different phases of the maize and bean growth under the different treatments. In the LR, 2012, there was significant interaction between time $\times$ tillage $\times$ cropping system $(\mathrm{p}=0.005)$. The sole bean $(14.74 \%)$ and the sole maize $(14.71 \%)$ had higher soil water content than maize and bean intercrop (14.65\%). In the SR, 2012, there was no significant variations of soil water content among the cropping system $(p=0.684)$. A time $\times$ cropping system interaction was observed $(p=0.003)$. In contrast to the $L R, 2012$, the sole maize plots had more soil water content $(14.21 \%)$ followed by bean $(14.19 \%)$ and intercrop $(14.02 \%)$ respectively. The intercrop had the lowest soil water content because of the increased plant population density per plot resulting in higher soil water extraction.

In the LR, 2013, there was no significant variations of moisture among the cropping system $(p=0.547)$. Time $\times$ cropping system interaction was observed $(\mathrm{p}=0.044)$. Sole bean plots had more soil water content $(9.48 \%)$ followed by intercrop $(9.20 \%)$ and sole maize $(9.05 \%)$ respectively. Cropping systems that offer quick surface cover (bean and intercrop) promote soil water conservation by reducing evaporation and increasing infiltration (Steiner, 2002). A three - season soil water content average as affected by cropping showed that sole bean had higher soil water $(12.80 \%)$ followed by sole maize $(12.66 \%)$ and the intercrop $(12.62 \%)$. This confirms that increased plant population density per plot result in higher moisture extraction from the soil. Soil water extraction by crops is determined not only by soil water content, evaporative demand and soil physical properties but also by physiological status of the crop (Passioura \& Angus, 2010).

\subsection{Effect of Tillage and Cropping Systems on Crop Performance Trends}

\subsubsection{Maize Height}

Maize plant height varied significantly over time in all the three seasons $(\mathrm{p}<0.001)$ (Table 2$)$. The final plant heights obtained in the different treatments were greatly influenced by the amount of rainfall in a particular season and thus the soil water content available to the crop. Plant height could be used as a measure of vegetative growth which sometimes reflects the amount of moisture available to the crops (Gicheru et al., 2004).

In the LR, 2012, the plant height was affected by tillage $(p=0.002)$, and a significant interaction of time $\times$ cropping system $(p=0.014)$. In the SR, 2012 season, an interaction of time $\times$ cropping system $(p<0.001)$ was also observed. In LR, 2012, tillage methods $(\mathrm{p}=0.002)$ showed a trend of $\mathrm{MBH}>\mathrm{MB}>\mathrm{OX}>\mathrm{H}>\mathrm{HTR}$ while 
in the SR, 2012, tillage, though not significant $(\mathrm{p}=0.246)$ showed a trend of $\mathrm{SR}>\mathrm{MB}>\mathrm{H}>\mathrm{MBH}>\mathrm{OX}>$ HTR. The tillage trend in LR, 2013, showed no significant interaction $(p=0.236)$ but a trend of MBH $>\mathrm{H}>$ MB $>$ SR $>$ OX $>$ HTR was observed. The height difference could be attributed to soil moisture conservation in the former plots and moisture difference in the soil. This contrast the fact that HTR maintained higher soil water levels throughout the LR, 2012 season and OX and SR in the SR, 2012 and LR, 2013 season. A probable cause of poor vegetative growth in the HTR plots was the inversion and mixing of top soil when constructing the tied ridges and this could have affected the fertility of the top soil. Some water ponding was also noted at the beginning of the season (LR and SR, 2012) in HTR plots which affected the germination and hence growth of the crops. Khurshid et al. (2006) reported taller plants in conventional tillage plots in comparison with that of minimum tillage in Faisalabad, Pakistan.

Sole maize had taller plants than the intercropped maize in all the seasons at the different weeks after planting (WAP) $(\mathrm{p}<0.001)$. This can be attributed to no competition for water, light and nutrients with the beans (Vandermeer, 1989). Increased plant height is advantageous because height is related to the final grain yield in that the stem of maize can serve as a reservoir of labile non structural carbohydrates which are mobilized as sugars and translocated to the filling grains during post flowering period. The stems also serve a role in maintaining the rate of grain filling against longer term effects of persistent post flowering stress such as drought (Edmeades and Lafitte, 1993). This phenomenon was observed in the current study in LR, 2013 as the maize seemed to produce very small or no maize cobs due to lack of evenly distributed rainfall during the growing season. There was too much rainfall at the start of the season and dry conditions set in which affected the growth of the crops (Kenya Meteorological Department [KMD], 2013).

\subsubsection{Cob Weights}

Maize cob weights were highly significantly affected $(\mathrm{p}<0.001)$ by season, tillage and cropping system, season $\times$ cropping system $(p=0.005)$ and season $\times$ tillage $(p=0.010)$ (Table 2). In the LR, 2012 season, tillage methods showed a trend of MBH $>\mathrm{OX}>\mathrm{MB}>\mathrm{H}>\mathrm{HTR}$ while in SR, 2012, MBH $>\mathrm{MB}>\mathrm{HTR}>\mathrm{SR}>\mathrm{H}>$ OX. In the LR, 2013, a trend of MBH $>$ MB $>\mathrm{H}>\mathrm{SR}>\mathrm{HTR}>\mathrm{OX}$ was observed. A three-season tillage average showed that $\mathrm{MBH}>\mathrm{MB}>\mathrm{OX}>\mathrm{H}>\mathrm{HTR}>\mathrm{SR}$. This results show that the conventional tillage practices had the highest cob lengths as compared to the conservation tillage.

Sole maize produced significantly higher weights $(8.51 \mathrm{Mg} / \mathrm{ha})$ as compared to intercrop $(7.59 \mathrm{Mg} / \mathrm{ha})$, which resulted in a $10.8 \%$ decrease in cob weight by intercropping in LR, 2012. On average across the three seasons, sole maize produced $5.88 \mathrm{Mg} / \mathrm{ha}$ and the intercrop $5.20 \mathrm{Mg} / \mathrm{ha}$ resulting in an $11.6 \%$ decrease by intercropping. Higher yields in sole crops indicate the relative competitive effect of intercrops compared to sole cropping. The average cob weight in the LR, 2012 was higher $(8.05 \mathrm{Mg} / \mathrm{ha}$ ) compared to the short rains, SR, 2012 with 5.64 $\mathrm{Mg} / \mathrm{ha}$ resulting to a $30 \%$ decrease from the long rain season to the short rain season within the year and a $58 \%$ decrease to the following season of LR, $2013(3.35 \mathrm{Mg} / \mathrm{ha})$. Ear initiation and grain filling for maize was greatly affected by the poor rainfall distribution in LR, 2013 (KMD, 2013). Occurrence of drought at the grain filling stage of maize reduces the photosynthetic rate and impairs assimilate translocation in kernels leading to reduced maize grain yield (Passioura \& Angus, 2010).

\subsubsection{Cob Lengths}

There was a seasonal effect as observed by the cob lengths $(\mathrm{p}<0.001)$ as shown in Table 2 . Though not significant $(\mathrm{p}=0.157)$, tillage showed a trend of MBH $>\mathrm{SR}>\mathrm{HTR}>\mathrm{MB}>\mathrm{OX}>\mathrm{H}$ in SR, 2012 and in LR, 2013, $\mathrm{MBH}>\mathrm{H}>\mathrm{MB}>\mathrm{SR}>\mathrm{OX}>\mathrm{HTR}$. A two - season average shows that $\mathrm{MBH}>\mathrm{MB}>\mathrm{SR}>\mathrm{H}>\mathrm{OX}>$ HTR, with an average length of $15.8 \mathrm{~cm}$. This results show that the conventional tillage practices had the highest cob lengths as compared to the conservation tillage.

There were no significant interactions by cropping systems $(p=0.272)$ but sole maize had slightly higher lengths than the intercropped maize in both seasons. Sole maize had an average of $15.92 \mathrm{~cm}$ and the intercrop $15.67 \mathrm{~cm}$. This may be as a result of the competition between beans and maize for the limiting soil nutrients. Turi et al. (2007) reported that difference of ear length among maize genotypes is a genetic characteristic which is affected by the environment and inputs.

\subsubsection{Maize Grain and Biomass Yields}

Grain yield is the important component of plant performance under a set of growing conditions. Any physiological or agronomic parameter at a given stage of growth would be of further use only when its effect is reflected on yield either way. Grain yield is a function of harvest index (HI) and dry matter production (Passioura \& Angus, 2010). 
Maize grain yield was highly significantly affected $(\mathrm{p}<0.001)$ by season, tillage and cropping system. A season and tillage interaction $(p=0.03)$ and cropping $\times$ season $(p=0.004)$ was also observed. In LR, 2012, the highest grain yield $(5.35 \mathrm{Mg} / \mathrm{ha})$ was observed in MBH and the lowest $(3.99 \mathrm{Mg} / \mathrm{ha})$ in HTR. For the SR, 2012, the highest grain yield $(8.93 \mathrm{Mg} / \mathrm{ha})$ was observed in $\mathrm{MBH}$ and the lowest $(3.33 \mathrm{Mg} / \mathrm{ha})$ in OX plots. In $\mathrm{LR}, 2013$, the highest grain yield was in MBH $(2.59 \mathrm{Mg} / \mathrm{ha})$ and lowest in $\operatorname{HTR}(1.81 \mathrm{Mg} / \mathrm{ha})$.

Biomass yields were affected by season $(p<0.001)$ and tillage $(p=0.008)$. In LR, 2012, the highest stover yield $(14.44 \mathrm{Mg} / \mathrm{ha}$ ) was observed in MBH and the lowest $(10.04 \mathrm{Mg} / \mathrm{ha})$ in H. For the SR, 2012, the highest biomass $(8.93 \mathrm{Mg} / \mathrm{ha})$ was observed in the case of HTR and the lowest $(5.72 \mathrm{Mg} / \mathrm{ha})$ in subsoiling - ripping (SR) plots. In LR, 2013, the highest stover yield was in MBH $(5.42 \mathrm{Mg} / \mathrm{ha})$ and lowest in OX $(4.28 \mathrm{Mg} / \mathrm{ha})$. There was a gradual decrease in the biomass from LR, 2012 to LR, 2013 and this is due to variation in rainfall differences which influenced soil moisture availability at the different stages of crop growth.

In the LR, 2012 season, the MB plots had lower moisture levels at both soil depths but gave higher maize (4.92 $\mathrm{Mg} / \mathrm{ha})$ and above ground biomass yields $(14.44 \mathrm{Mg} / \mathrm{ha})$ indicating that there was proper utilization of the moisture by the crops. HTR had high moisture levels due to the microbasin formation allowing storage and infiltration but gave the lowest maize grain yields (3.99 Mg/ha). During the early stages of the rainy season, the HTR plots experienced some water ponding and this might have resulted in poor aeration and germination hence the lower yields. This contrasts works done by Gichangi et al. (2003) working in semi-arid highlands area of Central Kenya found that tied ridging increased maize and bean yields. Miriti (2010) working in Makueni District, also found that maize yield was higher by $55 \%$ in the tied ridging plots, a contrast to this study findings.

In the SR, 2012 season, the OX and SR plots had high moisture levels throughout the season but gave the lowest maize grain yields $(3.3 \mathrm{Mg} / \mathrm{ha}$ and $3.37 \mathrm{Mg} / \mathrm{ha}$ respectively). This is contrast to work done by Rockstrom et al., (2009) in Kenya and Tanzania that indicated superior maize yields with ripping tillage as compared to the conventional tillage. This difference may be partly because their studies used mulch cover which was not applied in the current study. Biamah and Nhlabathi (2003) working over a period of four seasons in semi-arid Eastern Kenya reported that subsoiling/ ridging increased maize yields by an average of $23 \%$ and biomass by an average of $11 \%$ than the conventional tillage. Although Pikul and Aase (2003) showed that infiltration was consistently greater under subsoiling compared to conventionally tilled plots with no subsoiling, the benefits of subsoiling were not obvious in this study.

Intercropping affected the grain yield and biomass yield (Table 2). Intercropping significantly reduced ( $\mathrm{p}<$ 0.001 ) the three-season mean yields by $11 \%$ (from $3.71-3.31 \mathrm{Mg} / \mathrm{ha}$ ) in maize grain and $7.3 \%$ (from 8.19 $7.59 \mathrm{Mg} / \mathrm{ha}$ ) in biomass respectively. Higher yields in sole crops indicate the relative competitive effect of intercrops compared to sole cropping. Maize yield reduction in intercropped maize compared to the sole maize reductions have also been associated with interspecific competition in mixed stands and the absence of interspecific competition in the monocrops (Vandermeer, 1989). These yield variations also show that rainfall differences in the long and short rains influenced soil moisture availability at different stages of crop growth. Although yields of maize were lower in the maize-bean intercrop, the fact that two crops could be harvested in the same plot, more than compensated for the higher yields realized in the sole maize cropping system. The intercrop system may be better and preferable to the small scale farmers due to the dual purposes of ensuring food and nutritional security, as two crops are harvested in one season from the same land and improving soil fertility through biological nitrogen fixation. The potential advantages of intercropping include over yielding i.e. improved utilization of growth resources by the crop and improved reliability from season to season (Orindi \& Murrey, 2005; Gitonga et al., 2008; Odendo et al., 2011).

According to Government of Kenya (2010), the average maize yield is about $2 \mathrm{Mg} / \mathrm{ha}$; however, potential yields of over $6 \mathrm{Mg} / \mathrm{ha}$ are possible through the increased use of improved seed, fertilizer and crop husbandry practices. On average, the grain yield from all the treatments was $4.78 \mathrm{Mg} / \mathrm{ha}$ in $\mathrm{LR}, 2012,3.81 \mathrm{Mg} / \mathrm{ha}$ in $\mathrm{SR}, 2012$ and $2.16 \mathrm{Mg} / \mathrm{ha}$ in LR, 2013. This decline in yields over the seasons could be attributed to the rainfall distribution which varied in each season. This justifies that environmental factors play an important role on productivity of maize. The maize seed used was DH 02 , an early maturity (80-90 days), dryland hybrid that is drought tolerant, resistant to stem borers and adapted to low levels of nitrogen and thus performs better in semi-arid areas such as Mwala District (Kenya Seed Company, 2012). Thus considering the effects of a given environmental situation to maize production is too crucial in addition to crop and soil management practices. 


\subsubsection{Maize Harvest Index (HI)}

The HI data presented in Table 2, show there was a seasonal difference $(\mathrm{p}<0.001)$ with the highest HI in SR, $2012(28.5 \%)$. The trend by tillage was in the order of SR $>$ H $>$ MB $>$ MBH $>$ HTR $>$ OX. Intercropping systems produced lower yields compared to the monocrops. This is attributed to the resource competition of water and available nutrients in the soil by the two crops. It can also be attributed to soil moisture differences between long and short rains as influenced by the rainfall. According to Maobe et al. (2010), the magnitude of the maize harvest index is not highly heritable and varies with season, management and environment. A good HI is about $40 \%$ (Passioura \&Angus, 2010) and was not achieved in our study. Failure of treatments to impact on the maize $\mathrm{HI}$ in the seasons can be credited to poor distribution of rainfall at the grain filling stage. Crops that have poor water supply during grain filling may produce a large biomass but be unable to match that with a good harvest index (Passioura \& Angus, 2010).

Table 2. Maize number of cobs, grain yield, stover yield and harvest index as affected by seasons, tillage and cropping systems ( $\mathrm{n}=3$ seasons)

\begin{tabular}{|c|c|c|c|c|c|c|c|}
\hline Factor & $\begin{array}{l}\text { No of } \\
\text { cobs }\end{array}$ & $\begin{array}{l}\text { Cob } \\
\text { length } \\
(\mathrm{cm})\end{array}$ & $\begin{array}{l}\text { Cob weight } \\
\text { (Mg/ha) }\end{array}$ & $\begin{array}{l}\text { Grain yield } \\
(\mathrm{Mg} / \mathrm{ha})\end{array}$ & $\begin{array}{l}\text { Biological } \\
\text { yield (Mg/ha) }\end{array}$ & $\begin{array}{l}\text { Stover } \\
\text { yield } \\
(\mathrm{Mg} / \mathrm{ha})\end{array}$ & $\begin{array}{l}\text { Harvest } \\
\text { index (\%) }\end{array}$ \\
\hline \multicolumn{8}{|l|}{ Season (S) } \\
\hline LR, 2012 & - & - & 8.05 & 4.78 & 19.75 & 11.72 & 24.54 \\
\hline SR, 2012 & 12.48 & 16.58 & 5.64 & 3.81 & 13.40 & 7.75 & 28.53 \\
\hline LR, 2013 & 10.48 & 15.01 & 3.35 & 2.16 & 8.20 & 4.85 & 26.21 \\
\hline \multicolumn{8}{|l|}{ Tillage (T) } \\
\hline $\mathrm{H}$ & 11.06 & 15.84 & 5.45 & 3.51 & 12.76 & 7.31 & 27.67 \\
\hline HTR & 11.12 & 15.22 & 5.03 & 3.23 & 12.74 & 7.72 & 25.58 \\
\hline MB & 11.75 & 15.94 & 5.96 & 3.72 & 14.21 & 8.25 & 26.63 \\
\hline $\mathrm{MBH}$ & 12.00 & 16.46 & 6.43 & 4.01 & 15.69 & 9.26 & 26.32 \\
\hline $\mathrm{OX}$ & 11.06 & 15.39 & 5.52 & 3.43 & 13.58 & 8.06 & 25.64 \\
\hline SR & 11.88 & 15.93 & 4.51 & 3.00 & 10.71 & 6.19 & 27.81 \\
\hline Mean & 11.48 & 15.80 & 5.48 & 3.48 & 13.28 & 7.80 & 26.61 \\
\hline $\operatorname{LSD}(5 \%)$ & 0.618 & 0.976 & 1.321 & 0.774 & 3.27 & 2.014 & 2.109 \\
\hline \multicolumn{8}{|c|}{ Cropping system (C) } \\
\hline Sole maize (M) & 11.75 & 15.92 & 5.88 & 3.71 & 14.07 & 8.19 & 26.85 \\
\hline $\begin{array}{l}\text { Intercrop } \\
\text { (Maize+Bean) }\end{array}$ & 11.21 & 15.67 & 5.20 & 3.31 & 12.79 & 7.59 & 26.22 \\
\hline $\operatorname{LSD}(5 \%)$ & 0.380 & 0.459 & 0.7551 & 0.4450 & 1.869 & 1.151 & 1.205 \\
\hline CV \% & 3.4 & 2.1 & 5.3 & 4.4 & 5.1 & 5.8 & 3.7 \\
\hline
\end{tabular}

$\mathrm{H}=$ handhoe, $\mathrm{HTR}=$ handhoe + tied ridges, $\mathrm{MB}=$ Disc plough, $\mathrm{MBH}=$ Disc plough + harrowing, $\mathrm{OX}=$ ox-plough, $\mathrm{SR}=$ subsoiling-ripping, $\mathrm{S}=$ season, $\mathrm{T}=$ tillage, $\mathrm{C}=$ cropping system, $(-)=$ not measured in that season.

\subsubsection{Bean Grain and Biomass Yields}

Seasonal effects on bean grain yield, biological and biomass yields are shown by Table 3 . The biomass yields were affected by tillage $(p=0.046)$ with a trend of MBH $>$ HTR $>$ SR $>$ OX $>$ MB $>$ H while for grain yield ( $p$ $=0.057) \mathrm{MBH}>\mathrm{MB}>\mathrm{HTR}>\mathrm{SR}>\mathrm{OX}>\mathrm{H}$. In LR, 2012, the highest grain yield $(0.59 \mathrm{Mg} / \mathrm{ha})$ was observed in $\mathrm{MBH}$ and the lowest $(0.23 \mathrm{Mg} / \mathrm{ha})$ in handhoe $(\mathrm{H})$. For the $\mathrm{SR}, 2012$, the highest grain yield $(1.12 \mathrm{Mg} / \mathrm{ha})$ was observed in the case of HTR and the lowest $(0.73 \mathrm{Mg} / \mathrm{ha})$ in handhoe $(\mathrm{H})$. Mean seasonal grain yields was at 
$0.45 \mathrm{Mg} / \mathrm{ha}$ in LR, 2012 and $0.91 \mathrm{Mg} / \mathrm{ha}$ in the SR, 2012. No bean yield data was recorded in LR, 2013 due to poor rainfall distribution and prolonged drier conditions in the growing season (KMD, 2013).

In LR, 2012, the highest biomass yield $(1.23 \mathrm{Mg} / \mathrm{ha})$ was observed in $\mathrm{MBH}$ and the lowest $(0.64 \mathrm{Mg} / \mathrm{ha})$ in $\mathrm{H}$. For the SR, 2012, the highest biomass $(3.36 \mathrm{Mg} / \mathrm{ha})$ was observed in the case of HTR and the lowest $(2.31$ $\mathrm{Mg} / \mathrm{ha}$ ) in handhoe $(\mathrm{H})$. There was a gradual increase in biomass production from one season to the next indicative of variability in seasonal rainfall patterns.

Intercropping affected the grain yield and biomass yield (Table 3). Sole bean produced a grain yield of 0.68 $\mathrm{Mg} / \mathrm{ha}$ and biomass of $1.84 \mathrm{Mg} / \mathrm{ha}$ as compared to $0.67 \mathrm{Mg} / \mathrm{ha}$ and $1.78 \mathrm{Mg} / \mathrm{ha}$ of the intercrop respectively. Yield advantages from intercropping as compared to sole cropping are often attributed to mutual complimentary effects of component crops, such as better total use of available resources (Vandermeer, 1989). The greater canopy cover provided by maize-bean intercrop help reduce evaporation, regulate the soil temperature thus improve infiltration and therefore reduces the wastage of available water (Steiner, 2002). Bean yield in Sub Saharan Africa has been reported to be extremely low $(<1 \mathrm{Mg} / \mathrm{ha})$ compared to South America where yields are over $2 \mathrm{Mg} / \mathrm{ha}$ (Woomer, 2010; Odendo et al., 2011).

Table 3. Bean yields, biomass yields and harvest index as affected by season, tillage and cropping systems $(\mathrm{n}=2$ seasons)

\begin{tabular}{|c|c|c|c|c|}
\hline Factor & $\begin{array}{l}\text { Bean yield } \\
(\mathrm{Mg} / \mathrm{ha})\end{array}$ & $\begin{array}{l}\text { Biological yield } \\
(\mathrm{Mg} / \mathrm{ha})\end{array}$ & $\begin{array}{l}\text { Biomass yield } \\
(\mathrm{Mg} / \mathrm{ha})\end{array}$ & $\begin{array}{l}\text { Harvest index } \\
(\%)\end{array}$ \\
\hline \multicolumn{5}{|l|}{ Season $(\mathrm{S})$} \\
\hline LR, 2012 & 0.446 & 1.394 & 0.948 & 30.30 \\
\hline SR, 2012 & 0.905 & 3.575 & 2.670 & 25.58 \\
\hline \multicolumn{5}{|l|}{ Tillage (T) } \\
\hline $\mathrm{H}$ & 0.509 & 1.985 & 1.475 & 25.80 \\
\hline HTR & 0.756 & 2.862 & 2.111 & 28.85 \\
\hline MB & 0.767 & 2.518 & 1.751 & 30.25 \\
\hline MBH & 0.789 & 3.026 & 2.237 & 27.50 \\
\hline OX & 0.646 & 2.410 & 1.760 & 27.40 \\
\hline SR & 0.730 & 2.810 & 2.080 & 25.52 \\
\hline Mean & 0.699 & 2.602 & 1.903 & 27.55 \\
\hline $\operatorname{LSD}(5 \%)$ & 0.3184 & 1.214 & 0.9565 & 6.297 \\
\hline \multicolumn{5}{|l|}{ Cropping system (C) } \\
\hline Sole bean (B) & 0.682 & 2.523 & 1.844 & 29.10 \\
\hline $\begin{array}{l}\text { Intercrop (Maize + } \\
\text { Bean) }\end{array}$ & 0.670 & 2.450 & 1.775 & 26.80 \\
\hline $\operatorname{LSD}(5 \%)$ & 0.1786 & 0.6811 & 0.5366 & 3.533 \\
\hline $\mathrm{CV} \%$ & 23.6 & 20.0 & 19.1 & 8.6 \\
\hline
\end{tabular}

$\mathrm{H}=$ handhoe, $\mathrm{HTR}=$ handhoe + tied ridges, $\mathrm{MB}=$ Disc plough, $\mathrm{MBH}=$ Disc plough + harrowing, $\mathrm{OX}=$ ox-plough, $\mathrm{SR}=$ subsoiling-ripping, $\mathrm{S}=$ season, $\mathrm{T}=$ tillage, $\mathrm{C}=$ cropping system.

\section{Conclusion}

Soil moisture conservation has become an important issue during land preparation and crop growth due to climate change, which affects the amount of rainfall and the rainfall seasons. These results suggest that tillage methods and cropping system have an influence on soil moisture conservation and crop yields in the semi-arid areas of Kenya. Among the tillage treatments, MBH and MB were found to be more appropriate in improving crop yield and yield components of maize and beans. Inconsistencies in relative grain and biomass yields among tillage treatments are likely associated with the amount of soil moisture at the time of tillage/planting, growing 
season and prevailing climatic conditions during the growing seasons. Tillage experiments inconsistencies are due to the complexity of changes in soil properties caused by tillage. Therefore, it is necessary to examine the long-term effect of tillage at different locations and under various environmental and soil conditions so that more accurate generalizations can be made regarding the conditions required for sustainable tillage systems.

\section{Acknowledgements}

This study is supported by the Regional Universities Forum for Capacity Building in Agriculture (RUFORUM) and International Development Research Centre (IDRC).

\section{References}

Barron, J., Rockstrom, J., Gichuki, F., \& Hatibu, N. (2003). Dry spell analysis and maize yield for two semi-arid locations in East Africa. Agricultural and Forestry Meteorology, 17, 23-27. http://dx.doi.org/10.1016/S0168-1923(03)00037-6.

Biamah, E. K., \& Nhlabathi, N. (2003). Conservation tillage practices for dryland crop production in semi-arid Kenya: promotion of conservation tillage techniques for improving household food security in Iuni, Machakos, Kenya. In D. Beukes, S. Mkhize, H. Sally, \& L. Rensberg Van (Eds.), Proceedings of the symposium and workshop on water conservation technologies for sustainable dryland agriculture in SSA (WCT), held at Bloem Spa Lodge and Conference Centre, Bloemfontein, South Africa, 8-11 April, 2003.

Edmeades, G. O., \& Lafitte, H. R. (1993). Defoliation and plant density effects on maize selected for reduced $\begin{array}{lllll}\text { plant height. } & \text { Agronomy } & \text { Journal, } & 850-857 .\end{array}$ http://dx.doi.org/10.2134/agronj1993.00021962008500040014x

Fabrizzi, K. P., Garcia, F. O., Costa, J. L., \& Picone, L. I. (2005). Soil water dynamics, physical properties and corn and wheat responses to minimum and no-tillage systems in the southern Pampas of Argentina. Soil and Tillage Research, 81, 57-69. http://dx.doi.org/10.1016/j.still.2004.05.001.

Food and Agriculture Organization (FAO). (2008). Investing in Sustainable Agricultural Intensification. The Role of Conservation Agriculture. A Framework for Action. Food and Agriculture Organization of the United Nations, Rome.

Gichangi, E. M., Njiru, E. N., Itabari, J. K., Wambua, J. M., \& Maina, J. N. (2003). Promotion of improved soil fertility and water harvesting technologies through community-based on-farm trials in the ASALS of Kenya. Paper presented at the 1st Adaptive Research Conference held at KARI headquarters, Nairobi. 16th-19th June, 2003.

Gicheru, P. T., Gachene, C. K. K., \& Biamah, E. K. (1998). Effects of tillage and mulching on soil moisture conservation and crop production. Applied Plant Sciences, 12(1), 5-9.

Gicheru, P., Gachene, C., Mbuvi, J., \& Mare, E. (2004). Effects of soil management practices and tillage systems on surface soil water conservation and crust formation on a sandy loam in semi-arid Kenya. Soil and Tillage Research, 75, 175-184. http://dx.doi.org/10.1016/S0167-1987(03)00161-2

Gitonga, J. L., Ngeru, J. J., \& Liniger, H. P. (2008). Impacts of conservation tillage on soil water and crop production-A case study in the Northwest foot slopes of Mount Kenya. In T. Goddard, M. A. Zoebisch, Y. T. Gan, W. Ellis, A. Watson, \& S. Sombatpanit (Eds.), No-Till Farming systems (pp. 373-382). Special Publication No.3, World Association of Soil and Water Conservation, Bangkok.

Government of Kenya. (2010). Agricultural Sector Development Strategy, 2010-2020. Government of Kenya.

Guzha, A. C. (2004). Effects of tillage on soil micro-relief, surface depression storage and soil water storage. Soil and Tillage Research, 76, 105-114. http://dx.doi.org/10.1016/j.still.2003.09.002

Kenya Meteorological Department. (KMD). (2013). Review of rainfall during the long rains (March-May) 2013 season. Ref No: KMD/FCST/5 - 2013/SO/06. 4th June, 2013. Nairobi, Kenya.

Kenya Seed Company. (2012). Maize and legumes: description and planting guide. Retrieved July 20, 2012 from www.kenyaseed.com

Khurshid, K., Iqbal, M., Arif, M. S., \& Nawaz, A. (2006). Effect of tillage and mulch on soil physical properties and growth of maize. International Journal of Agriculture and Biology, 8(5), 593-596.

Landon, J. R. (1991). Booker Tropical Soil Manual. A Handbook for Soil Survey and Agricultural Land Evaluation in the Tropics and Subtropics. Longman, New York. 
Manyatsi, A. M., Mhazo, N., Mkhatshwa, M., \& Masarirambi, M. T. (2011). The effect of different in-situ water conservation tillage methods on growth and development of Taro (Colocasia esculenta L.). Asian Journal of Agricultural Sciences, 3(1), 11-18.

Maobe, S. N., Akundabweni, L. S. M., Mburu, M. W. K., Ndufa, J. K., Mureithi, J. G., Gachene, C. K. K., ... Okello, J. J. (2010). Effect of Mucuna green manure and inorganic fertilizer, Urea Nitrogen sources and application rates on harvest index of maize (Zea Mays L.). World Journal of Agricultural Sciences, 6(5), 532-539.

Miriti, J. M. (2010). Effects of conservation tillage on soil properties, moisture conservation and yield of maize and cowpea in semi-arid Eastern Kenya. PhD Thesis, University of Nairobi.

Motsi, K. E., Chuma, E., \& Mukamuri, B. B. (2004). Rainwater harvesting for sustainable agriculture in communal lands of Zimbabwe. Physics and Chemistry of the Earth, 29(15-18), 1069-1079. http://dx.doi.org/10.1016/j.pce.2004.08.008.

Mujdeci, M., Kara, B., \& Isildar, A. A. (2010). The effects of different soil tillage methods on water dynamics. Scientific Research and Essays, 5(21), 3345-3350.

Ngugi, R. K., Mureithi, S. M., \& Kamande, P. N. (2011). Climate forecast information: the status, needs and expectations among smallholder agro-pastoralists in Machakos District, Kenya. International Journal of Current Research, 3(11), 6-12.

Odendo, M., Bationo, A., \& Kimani, S. (2011). Socio-economic contribution of legumes to livelihoods in Sub-Saharan Africa. In A. Bationo et al. (Eds.), Fighting poverty in Sub-Saharan Africa: the multiple roles of legumes in Integrated Soil Fertility Management (pp. 27-46). Springer Science and Business Media. http://dx.doi.org/10.1007/978-94-007-1536-3_2

Okalebo, J. R., Gathua K. W., \& Woomer, P. L. (2002). Laboratory methods of soil and plant analysis: A working Manual (2nd ed.). TSBF-CIAT and Sacred Africa, Nairobi, Kenya.

Orindi, V. A., \& Murrey, L. A. (2005). Adapting to climate change in East Africa: Strategic approach. Gatekeeper Series 1117. International Institute for Environment and Development (IIED).

Passioura, J. B., \& Angus, J. F. (2010). Improving productivity of crops in water-limited environments. Advances in Agronomy, 106, 37-75. http://dx.doi.org/10.1016/S0065-2113(10)06002-5

Pikul, J. L., \& Aase, J. K. (2003). Water infiltration and storage affected by sub soiling and subsequent tillage. Soil Science Society of America Journal, 67, 859-866. http://dx.doi.org/10.2136/sssaj2003.0859

Rashidi, M., \& Keshavarzpour, F. (2008). Effect of different tillage methods on soil physical properties and crop yield of melon (Cucumis melo). ARPN Journal of Agricultural and Biological Science, 3(2), 41-46.

Rockstrom, J., Barron, J., \& Fox, P. (2003). Water productivity in rainfed agriculture: Challenges and opportunities for smallholder farmers in drought prone tropical agroecosystem. CABI, IWMI, Wallingford, UK, Colombo, Sri Lanka. PMid:14728794, PMCid:PMC1693286.

Rockstrom, J., Kaumbutho, P., Mwalley, J., Nzabi, A. W. M., Temesgen, M. L., Mawenya, L., ... Damgaard-Larsen, S. (2009). Conservation farming strategies in East and Southern Africa: Yields and rain water productivity from on-farm action research. Soil and Tillage Research, 103, 23-32. http://dx.doi.org/10.1016/j.still.2008.09.013.

Steiner, K. (2002). Crop residue management and cover crops. African Conservation Tillage Network Information series No. 3. Harare: ACT.

Turi, N. A., Shah, S. S., Ali, S., Rahman, H., Ali, T., \& Sajjad, M. (2007). Genetic variability for yield parameters in maize (Zea Mays L.) genotypes. Journal of Agricultural and Biological Sciences, 2(4-5), 1-3.

Unger, P. W., Stewart, B. A., Parr, J. F., \& Singh, R. P. (1991). Crop residue management and tillage methods for conserving soil and water in the semi-arid regions. Soil and Tillage Research, 20, 219-240. http://dx.doi.org/10.1016/0167-1987(91)90041-U.

Vandermeer, J. H. (1989). The ecology of intercropping. Cambridge, UK: Cambridge University Press. http://dx.doi.org/10.1017/CBO9780511623523

Wamari, J. O., Sijali, V. I., Kheng, L. H., Miriti, J. M., \& Esilaba, A. O. (2012). Use of Aquacrop model to predict maize yields under varying rainfall and temperature in a semi-arid environment in Kenya. Journal of Meteorology and Related Sciences, 6, 23-32. 
Woomer, P. L. (2010). Biological nitrogen fixation and grain legume enterprise: Guidelines for N2Africa Master Farmers. Tropical Soil Biology and Fertility Institute of the International Centre for Tropical Agriculture. Nairobi.

\section{Copyrights}

Copyright for this article is retained by the author(s), with first publication rights granted to the journal.

This is an open-access article distributed under the terms and conditions of the Creative Commons Attribution license (http://creativecommons.org/licenses/by/3.0/). 